ORIGINAL ARTICLE

\title{
Seatbelt use by high school students
}

\author{
A F Williams, A T McCartt, L Geary
}

Injury Prevention 2003;9:25-28

\begin{abstract}
Objective: To determine seatbelt use of teenage drivers arriving at high schools in the morning and at evening football games compared with belt use of adults driving teenage passengers to these events, and teenage passenger belt use depending on whether they were being driven by another teenager or an adult.

Methods: Unobtrusive observations of belt use were made at 12 high schools in Connecticut and Massachusetts.

Results: Among males, teenage drivers had lower belt use than adults; differences between female teenage and female adult drivers were slight. Teenage passengers had lower belt use in vehicles driven by other teenagers than in cars driven by adults, but more than $40 \%$ of teenage passengers in vehicles driven by adults, presumed in most cases to be the teenager's parent, were not belted. Teenage passenger belt use was lower than teenage driver use regardless of gender. These differences were found both at morning arrivals and at football games, but teenage belt use was not much different in these two settings. Teenage passengers were belted more often if drivers were belted, whether the driver was another teenager or an adult, but a third of male passengers and $25 \%-30 \%$ of female passengers were unbelted even when drivers were belted. Conclusion: Teenagers have high crash risk but low belt use, which adds to their injury problem. Avenues to address this include strong belt use laws and their enforcement, building belt use requirements into graduated licensing systems, keeping young beginners out of high risk driving situations, and finding ways to influence parents and other adults to ensure that their teenage passengers use seatbelts.
\end{abstract}

See end of article for authors' affiliations Correspondence and reprint requests to: Dr Allan F Williams, 1005 North Glebe Road, Arlington, VA 22201-4751, USA; awilliams@iihs.org

T eenage drivers have higher crash risk than adults. Yet studies have found that many teenagers do not use seatbelts, making them more vulnerable to crash injuries. In one series of studies, seatbelt use of student drivers arriving at high schools was observed at the same Maryland schools in 1982, 1988, and $1995 .^{1-3}$ Maryland's seatbelt use law went into effect in 1986, so these studies allowed tracking of belt use rates before and after the law and over time. Remarkable progress has been achieved. For example, at one high school, driver belt use was $1 \%$ in $1982,29 \%$ in 1988 , and $52 \%$ in 1995 . At another, belt use rose from $3 \%$ to $44 \%$ to $68 \%$. In all the surveys, however, high school drivers were generally less likely than adult drivers in the surrounding community to be belted, although in the 1995 survey there was some evidence that student and adult use rates were converging. That is, belt use by student drivers was the same as adult driver use at one of the high schools and higher at another, whereas in prior surveys student belt use was lower than adult use at all the schools.

Belt use by teenage passengers, however, is consistently lower than adult passenger use and much lower than teenage driver use. In the 1995 high school survey, teenage passenger use averaged about 20 percentage points lower than for teenage drivers. An extensive observational study of drivers and front seat passengers conducted in 1995 found differences of 4-14 percentage points between teenage and adult belt use in eight cities in four states, with teenage front seatbelt use ranging from $20 \%$ to $58 \% .{ }^{4}$ Clearly low belt use by teenage drivers and passengers adds to their motor vehicle injury problem.

Since 1995, graduated licensing systems for young beginners have been introduced in most states. These systems are premised on reducing exposure to high risk driving situations while people are learning, most notably late night travel and travel with passengers. Crash risk increases incrementally with the number of passengers. ${ }^{5}$ A recent study addressing the situational nature of seatbelt use among fatally injured drivers found that belt use among teenage drivers who died was lowest in these high risk situations - that is, late at night and when with passengers, especially multiple passengers. ${ }^{6}$ Belt use among fatally injured teenage passengers also decreased as vehicle occupancy increased. These findings show the importance of restricting these activities, not only because of the higher crash risk but because of the extra injury likelihood. They also raise the question of whether belt use in general should be addressed in graduated licensing systems.

The situational belt use study was based on fatally injured drivers and passengers. In the present study observations of belt use were made at high schools in two states. Two situations were observed: when arriving in the morning to attend classes and when arriving for a Friday evening football game. Observations were made of teenage drivers, adult drivers transporting teenagers (presumably mostly parents), and teenage front seat passengers. The study provided the opportunity to update information on belt use of high school drivers and passengers. It also allowed belt use to be assessed in a recreational setting, one that may have somewhat higher crash risk than driving to high school in the morning. The study design also allowed a comparison of teenage belt use rates with that of adults arriving at the schools; an assessment of belt use of teenage drivers and passengers in relation to the number and types of other occupants in the vehicle; and an assessment of the relationship between teenage passenger and driver belt use, depending on whether the driver was an adult or another teen.

\section{METHODS}

Observations of seatbelt use were made at 12 high schools in the fall of 2001. Six public high schools were selected in each of two contiguous Northeastern states, Connecticut and Massachusetts. Connecticut has a primary seatbelt law (that is, police may stop vehicles solely for belt law violations) and Massachusetts has a secondary seatbelt law. 


\section{Selection of schools}

A sample of schools in each state was sought that would provide a balanced cross section in terms of sociodemographic characteristics and location and that would yield an adequate sample of unobtrusive and accurate observations of almost all students arriving in a passenger vehicle in the morning and at a football game. It was determined that positioning observers on public streets at all school entrances would maximize the ability to conduct observations unobtrusively and would yield the largest and most representative sample.

The following schools were excluded: private, vocational/ technical, and charter schools, and schools with fewer than 400 students enrolled in the junior and senior classes combined. In Massachusetts, schools within 10 miles of Boston and schools on Cape Cod, Nantucket, and Martha's Vineyard were excluded because there were no comparable areas in Connecticut. Four Connecticut schools that served a school district with a per capita annual income greater than \$55 000 were also excluded. There remained approximately 75 schools in each state. These schools were then evaluated in terms of the possibilities for making unobtrusive observations of most vehicles arriving at schools in the morning and at football games.

Following site visits to 24 Connecticut and 33 Massachusetts schools that appeared promising, six schools were selected in each state that provided a mix of rural, suburban, and urban settings and a range of per capita annual income. The per capita annual income ranged from \$21 915 to \$30 220 for the six Connecticut school districts and from \$22 771 to $\$ 32088$ for the six Massachusetts school districts. The states' samples of schools were well matched in terms of population density; in each state there were four school districts with population density between 1000-2000 residents/square mile, one district with population density less than 500 persons/ square mile, and one district with population density greater than 2000 persons/square mile.

\section{Seatbelt observations}

Observation data were collected from early October to mid-November, 2001. Students were observed as they arrived at school on a Thursday or Friday morning, and as they arrived at a Friday evening football game. For all but two schools, the morning and evening observations were conducted on the same day. The morning observations at the remaining schools were conducted on the Thursday after the evening observations. All the football games began between 6:00 pm and 7:00 pm, and observations began approximately one hour earlier. All the schools started classes at approximately 7:30 am and observations began approximately one half hour earlier.

Observations were conducted by teams of two observers standing side by side at each entrance/exit to the school campus, excluding entrances/exits used solely for school bus drop-offs. Observations were conducted only for those vehicles with a teenage driver or teenage front seat outboard passenger. The following information was collected for qualifying vehicles: driver gender, estimated age (teenager younger than 20, young adult age 20-25, adult older than 25), and shoulder belt use; front seat outboard passenger gender, age, and shoulder belt use; number of back seat passengers; license plate number. Although the observers attempted to observe each qualifying vehicle passing through the entrance, any skipped qualifying vehicle was noted.

In all, data were collected for 3638 vehicles ( 1434 in Massachusetts and 2204 vehicles in Connecticut) during the morning observations and for 1966 vehicles (957 vehicles in Massachusetts and 1009 in Connecticut) during the evening observations. An additional 674 vehicles (378 in Massachusetts and 296 in Connecticut) were "skipped" during the morning observations; 58 vehicles (32 in Massachusetts and 26 in Connecticut) were skipped during the evening observations.
Table 1 Seatbelt use of teenage and adult drivers arriving at 12 high schools in Connecticut and Massachusetts in the morning and for evening football games; values are percent (number)

\begin{tabular}{llllll}
\hline & \multicolumn{2}{l}{ Teenage drivers } & & \multicolumn{2}{l}{ Adult drivers } \\
\cline { 2 - 3 } \cline { 5 - 6 } & Morning & Football & & Morning & Football \\
\hline Connecticut & & & & & \\
1 & $41(168)$ & $43(51)$ & & $55(192)$ & $58(43)$ \\
2 & $58(130)$ & $53(111)$ & & $64(98)$ & $80(120)$ \\
3 & $64(157)$ & $57(75)$ & & $63(166)$ & $76(51)$ \\
4 & $67(109)$ & $67(72)$ & & $72(199)$ & $76(70)$ \\
5 & $70(152)$ & $49(57)$ & & $69(185)$ & $49(65)$ \\
6 & $81(140)$ & $55(65)$ & & $74(156)$ & $78(93)$ \\
Massachusetts & & & & & \\
1 & $48(206)$ & $46(82)$ & & $66(117)$ & $80(61)$ \\
2 & $57(162)$ & $53(101)$ & & $68(87)$ & $72(116)$ \\
3 & $58(138)$ & $55(118)$ & & $70(98)$ & $87(100)$ \\
4 & $61(181)$ & $67(75)$ & $73(142)$ & $66(65)$ \\
5 & $70(187)$ & $62(98)$ & $69(77)$ & $72(102)$ \\
6 & $71(154)$ & $60(110)$ & $87(108)$ & $71(94)$ \\
Weighted total & 62 & 56 & & 68 & 74 \\
& $(\mathrm{n}=1884)$ & $(\mathrm{n}=1015)$ & $(\mathrm{n}=1625)$ & $(\mathrm{n}=987)$ \\
\hline
\end{tabular}

\section{Analysis}

Initial analysis indicated few important between-state differences in observed patterns of belt use. Therefore, the data from the two states were combined in all subsequent analyses. The mean number of observations conducted per school was 467 (including both morning and evening observations), and the number of observations per school ranged from 362 to 703 . All analyses reported here were conducted with data weighted to equalize the sample sizes across the 12 schools. The weights ranged from 0.66 to $1.29 ; \chi^{2}$ tests were used to assess statistical significance.

\section{RESULTS}

Based on the weighted sample, observations of shoulder belt use were made for 2899 teenage drivers, 2612 adult drivers, and 4206 front seat teenage passengers at the 12 high schools. Fifty six percent of the teenage drivers were male, compared with $41 \%$ of the adult drivers and $46 \%$ of the teenage passengers. For teenage passengers, 2582 were traveling with adult drivers and 1624 were with teenage drivers. There were 6152 total belt observations made at morning arrival and 3565 at the football games. Tables $1-3$ provide the main results.

\section{Variation by school and gender}

Although not the focus of the study, it is clear from tables 1-3 that belt use varied by school and by gender. For example, belt use among teenage drivers arriving at high schools in the morning ranged from $41 \%$ to $81 \%$ (table 1 ). Some of the variation by school may be because of the relatively small numbers involved, but differences in socioeconomic status of the area in which the high school is located has explained some of the variation in belt use in prior studies at high schools. In the present study, median household income was related to adult driver belt use $(r=0.58, \mathrm{p}=0.047)$ but not to teenage driver use $(r=0.24, \mathrm{p}=0.453)$.

Table 3 indicates that, as is typical, seatbelt use by females was higher than for males. This was so for teenage drivers, adult drivers, and teenage passengers, both at morning arrivals and at football games. The only comparison in table 3 that was not statistically significant $(\mathrm{p}=0.05)$ was between male $(73 \%)$ and female $(75 \%)$ adult drivers arriving at football games. 
Table 2 Seatbelt use of teenage front seat passengers with either teenage or adult drivers arriving at 12 high schools in Connecticut and Massachusetts in the morning and for evening football games; values are percent (number)

\begin{tabular}{llllll}
\hline & \multicolumn{2}{l}{ Teenage drivers } & & \multicolumn{2}{l}{ Adult drivers } \\
\cline { 2 - 3 } \cline { 5 - 6 } & Morning & Football & & Morning & Football \\
\hline Connecticut & $24(79)$ & $46(37)$ & & $41(186)$ & $60(43)$ \\
1 & $49(55)$ & $53(64)$ & & $69(93)$ & $64(121)$ \\
2 & $49(91)$ & $51(37)$ & & $52(165)$ & $63(51)$ \\
3 & $43(54)$ & $41(41)$ & & $60(197)$ & $60(70)$ \\
4 & $51(78)$ & $29(28)$ & & $52(184)$ & $43(63)$ \\
5 & $74(69)$ & $50(36)$ & $62(157)$ & $68(91)$ \\
6 & $39(125)$ & $44(45)$ & & $43(115)$ & $39(61)$ \\
Massachusetts & $34(105)$ & $48(65)$ & & $46(87)$ & $54(115)$ \\
1 & $35(96)$ & $44(66)$ & & $37(97)$ & $63(106)$ \\
2 & $59(111)$ & $59(51)$ & & $56(139)$ & $55(66)$ \\
3 & $59(87)$ & $63(46)$ & & $59(76)$ & $71(99)$ \\
4 & $56(90)$ & $54(68)$ & $71(107)$ & $62(93)$ \\
5 & 47 & 49 & & 54 & 60 \\
6 & $(\mathrm{n}=1040)$ & $(\mathrm{n}=584)$ & $(\mathrm{n}=1603)$ & $(\mathrm{n}=979)$ \\
Weighted total & 47 & & & &
\end{tabular}

Table 3 Seatbelt use of teenage and adult drivers and their teenage passengers, by gender; values are percent (number)

\begin{tabular}{|c|c|c|c|c|}
\hline & \multicolumn{2}{|c|}{ Morning } & \multicolumn{2}{|c|}{ Football } \\
\hline & Male & Female & Male & Female \\
\hline Adult driver & $\begin{array}{l}63 \\
(592)\end{array}$ & $\begin{array}{l}71 \\
(1032)\end{array}$ & $\begin{array}{l}73 \\
(472)\end{array}$ & $\begin{array}{l}75 \\
(510)\end{array}$ \\
\hline $\begin{array}{l}\text { Teenage passenger with adult } \\
\text { driver }\end{array}$ & $\begin{array}{l}50 \\
(721)\end{array}$ & $\begin{array}{l}56 \\
(884)\end{array}$ & $\begin{array}{l}52 \\
(410)\end{array}$ & $\begin{array}{l}64 \\
(569)\end{array}$ \\
\hline Teenage driver & $\begin{array}{l}54 \\
(993)\end{array}$ & $\begin{array}{l}70 \\
(890)\end{array}$ & $\begin{array}{l}49 \\
(628)\end{array}$ & $\begin{array}{l}69 \\
(389)\end{array}$ \\
\hline $\begin{array}{l}\text { Teenage passenger with } \\
\text { teenage driver }\end{array}$ & $\begin{array}{l}42 \\
(494)\end{array}$ & $\begin{array}{l}52 \\
(544)\end{array}$ & $\begin{array}{l}43 \\
(301)\end{array}$ & $\begin{array}{l}57 \\
(286)\end{array}$ \\
\hline
\end{tabular}

\section{Teenage drivers $\mathbf{v}$ adult drivers}

As table 3 indicates, male teenage drivers had lower belt use than male adult drivers, both in the morning (54\% v 63\%, $\mathrm{p}<0.001)$ and at football games $(49 \% v 73 \%, \mathrm{p}<0.001)$. For female drivers, there was no difference in the morning between teenagers and adults $(70 \% v 71 \%)$ and the difference at the football games was only marginally significant $(69 \% v$ $75 \%, \mathrm{p}=0.054)$.

\section{Teenage passenger belt use with teenage $v$ adult drivers}

Teenage passengers in cars driven by other teenagers had lower belt use than teenagers in cars driven by adults. This was true particularly for males (morning: $42 \%$ v 50\%, $\mathrm{p}=0.005$; football: $43 \% \vee 52 \%, \mathrm{p}=0.012$ ) and to a lesser extent for females (morning: $52 \% \vee 56 \%, \mathrm{p}=0.10$; football: $57 \% \vee 64 \%$, $\mathrm{p}=0.029)$.

\section{Teenage passenger $\boldsymbol{v}$ teenage driver belt use}

Table 3 also shows that teenage passengers with teenage drivers had lower belt use than teenage drivers regardless of driver gender. This was true for all comparisons: males/morning: $42 \% \vee 54 \%, \mathrm{p}<0.001$; males/football: $43 \% \vee 49 \%, \mathrm{p}=0.103$; females/morning: $52 \% v 70 \%$, p $<0.001$; females/football: $57 \%$ $v 69 \%, \mathrm{p}=0.001)$. When only the cars containing teenage drivers and front seat teenage passengers were included (that is,
Table 4 Teenage passenger belt use in relation to driver belt use; values are percent

\begin{tabular}{lcclll}
\hline & \multicolumn{3}{c}{ Morning } & & \multicolumn{2}{l}{ Football } \\
\cline { 2 - 3 } \cline { 5 - 5 } & Male & Female & & Male & Female \\
\hline Teenage driver belt use & 66 & 71 & 67 & 78 \\
Yes & 10 & 20 & 16 & 26 \\
No & 64 & 68 & 66 & 74 \\
Adult driver belt use & & 30 & 23 & 34 \\
Yes & 22 & & & \\
No & & & &
\end{tabular}

drivers with no passengers were excluded), teenage driver belt use in the morning was $61 \% \vee 47 \%$ for their teenage passengers $(p<0.001)$. At football games, $55 \%$ of the teenage drivers and $49 \%$ of the teenage passengers were belted $(\mathrm{p}=0.074)$.

\section{Variation by setting}

There were some differences in belt use between the two settings in which observations were made. For males, teenage driver belt use was lower at football games (49\% v 54\%, $\mathrm{p}=0.023)$, while adult driver usage was higher at games $(73 \%$ $v 63 \%, \mathrm{p}=0.001)$. For females, teenage passenger use was somewhat higher at football games, both with teenage drivers $(57 \% \vee 52 \%, \mathrm{p}=0.205)$ and adult drivers $(64 \% \vee 56 \%$, $\mathrm{p}=0.002$ ).

Clearly there was some degree of individual variation in belt use in the two settings in which observations were made. Among the 122 teenage drivers assumed to have been observed in both settings (same sex, same license tag), $66 \%$ were consistent in their belt use, either using or not using on both occasions. Nineteen percent were belted in the morning but not at the football game; 16\% were unbelted in the morning but belted at the game.

\section{Teenage passenger belt use in relation to driver use}

Both male and female teenage passengers were much more likely to use belts if the driver was belted, whether the driver was another teenager or an adult. These relationships are shown in table 4. For example, when arriving at high schools in the morning, $66 \%$ of male teenage passengers in the cars of teenage drivers were belted if the driver was, compared with $10 \%$ if the driver was unbelted. However, about a third of male passengers and $25 \%-30 \%$ of female passengers were unbelted even when drivers were belted.

Both male and female adult drivers had a similar influence on their teenage passengers. For example, in the morning observation, if adult male drivers were belted $67 \%$ of their teenage passengers were, compared with $28 \%$ if drivers were not belted. If female adult drivers were belted, $66 \%$ of their teenage passengers were, compared with $25 \%$ if the adult was not belted.

\section{Unbelted teenage passengers with adult drivers}

Most adult drivers observed in this study are assumed to be parents, particularly when dropping off students in the morning. Although teenage passenger and adult belt use were highly correlated, it is revealing to see the frequency with which teenage passengers were unbelted when traveling in cars driven by adults presumed to be their mothers or fathers. For example, when dropping their children off at school in the morning, the overall use rate for adults was $68 \%$ compared with $54 \%$ for their children. Both were buckled on $46 \%$ of the morning trips, neither was buckled on $23 \%$ of the trips, the adults but not the teenage passengers were buckled in $23 \%$ of the occasions, and the teenage passengers but not the parents 
were buckled on the remaining $8 \%$ of the trips. Thus, when in cars driven by their presumed parents, $46 \%$ of teenage passengers in the front seat were unbelted. In 50\% of these cases of unbelted teenage passengers, the adult drivers were belted.

\section{Teenage driver and passenger belt use by number of vehicle occupants}

There were no significant relationships between teenage driver belt use and the presence or number of teenage passengers either in the morning or at football games. For example, $64 \%$ of those driving alone in the morning were belted, compared with $60 \%$ when there was one teenage passenger, and $62 \%$ when there were two or more $(p=0.439)$. Nor was there a significant relationship between teenage passenger belt use and the presence of additional passengers when they were in cars driven by other teenagers. In the morning, when there was only one teenage passenger, $47 \%$ were using belts compared with $49 \%$ when there were three occupants and $43 \%$ when there were four or more $(p=0.648)$.

\section{DISCUSSION}

The study generally confirms that teenagers in the front seats of vehicles have relatively low belt use. For drivers, however, low belt use relative to adults was limited to male teenagers. Teenage belt use was not found to be lower in a more recreational setting. Male teenage driver belt use was lower at football game arrivals than when arriving for school in the morning, but female teenage passenger belt use was higher at football games. It is possible that other recreational settings, for example, leaving the football game or social settings more likely to involve alcohol use, would result in lower belt use. Belt use was inconsistent for one third of the teenagers observed in both settings, that is, they were belted on one occasion but not the other.

The presence of teenage drivers and teenage passengers together in a car elevates crash risk and reduces belt use. However, there was no evidence in this study of decreases in either teenage driver or teenage passenger belt use as occupancy of the vehicle increased. This is contrary to the findings of a study of belt use based on fatally injured teenage drivers and passengers, ${ }^{6}$ but the finding that teenage driver belt use did not decrease as the number of teenage passengers increased is consistent with a prior observational study of teenage occupants. ${ }^{4}$ The reasons for this different result are unknown, but may reflect differences in characteristics of drivers and their passengers in fatal crashes compared with those not in crashes. In any case, the low belt use of teenagers, generally, is cause for concern.

There was considerable variation in both teenage and adult belt use within each state, but negligible differences in belt use overall between the two states. This was so even though Connecticut has a primary law and the reported statewide use rate in Connecticut $(76 \%)$ is considerably higher than in Massachusetts $(50 \%)$. Nevertheless, laws and their enforcement are a proven way to increase belt use, and high crash risk, low belt use populations such as teenagers need special attention. Changing belt use laws so that motorists can be stopped expressly for not using seatbelts has been shown to yield overall increases in belt use of $10 \%-15 \%{ }^{7}$ Highly publicized enforcement of belt use laws also increases use, and seatbelt checkpoint and patrol activities should include locations frequented by teenage drivers. Belt use requirements also can be built into graduated licensing systems. North Carolina has taken this approach, imposing a higher fine (up to \$100) than the general belt use law (\$25) and delaying graduation. If publicized and enforced, such provisions can increase use.

Graduated licensing provisions are designed to keep young beginners out of late night and other high crash risk situations

\section{Key points}

- Based on observations of vehicles arriving at high schools, male teenage drivers and male and female teenage passengers had low belt use.

- Passenger belt use was especially low among teenagers being transported by teenage drivers, but many teenagers being driven by adults were not belted.

- Strong laws and their enforcement increase belt use. Teenagers need special attention in enforcement campaigns.

- Graduated licensing systems can include special penalties for belt non-use, as well as provisions designed to keep teenagers out of high crash risk situation, such as passenger restrictions.

while they are learning. In particular, restrictions on carrying teenage passengers would address both the problems of high crash risk and low belt use. Interestingly, at the time of the study, Massachusetts had in place a restriction on transporting non-family members younger than age 18 for the first six months of licensure, unless a 21 year old license holder was present. Presumably some of the Massachusetts drivers observed were under this restriction, but upon arrival at school $60 \%$ of the Massachusetts teenagers had a teenage passenger in the car compared with 50\% of Connecticut teenagers, who were not subject to such a restriction, and about equal percentages $(57 \%$ in Connecticut, 59\% in Massachusetts) had teenage passengers at football games.

Parents have primary responsibility for the safety for their children. It is surprising how often teenagers were unbelted when they were traveling with their parents. Combining morning and evening observations, $44 \%$ of teenagers were not belted when with adult drivers, many of whom were themselves belted. Clearly many parents and other adults still need to be convinced of the importance of requiring teenagers to use seatbelts whenever they travel in vehicles.

\section{IMPLICATIONS FOR PREVENTION}

Low belt use by teenage drivers and passengers aggravates their injury problem. There are known ways to increase belt use, featuring strong laws and their enforcement. These techniques need more vigorous application in general, and in particular for high crash risk populations such as teenagers.

\section{ACKNOWLEDGEMENT}

This work was supported by the Insurance Institute for Highway Safety.

\section{Authors' affiliations}

A F Williams, Insurance Institute for Highway Safety, Arlington, Virginia A T McCartt, L Geary, Preusser Research Group, Inc, Trumbull, Connecticut

\section{REFERENCES}

Williams AF, Wells JK, Lund AK. Voluntary seat belt use among high school students. Accid Anal Prev 1983;15:161-5

2 Wells JK, Williams AF, Teed NJ, et al. Belt use among high school students. Arlington, VA: Insurance Institute for Highway Safety, 1989.

3 Williams AF, Rappold V, Ferguson SA, et al. Seat belt use of high Williams AF, Rappold V, Ferguson SA, et al. Seat belt use of high
school drivers and their passengers. J Traffic Med 1997:25:21-5. school drivers and their passengers. J Traffic Med 1997; 25:21-5.
4 Womack KN, Trout NH, Davies BJ. Characteristics and conditions of teenage safety belt use. Report No DOT HS-808-676. Washington, DC: National Highway Traffic Safety Administration, 1997.

5 Chen L, Baker SP, Braver ER, Li G. Carrying passengers as a risk factor for crashes fatal to 16 - and 17 -year-old drivers. JAMA 2000;283:1578-82.

6 Williams AF, Shabanova V. Situational factors in seat belt use by teenage drivers and passengers. Traffic Inj Prev 2002;3:201-4.

7 Solomon MG, Cosgrove LA, Preusser DF. A summary of results from studies measuring the change from secondary enforcement of safety belt laws to primary enforcement; emphasizing the effects on race. Presented at the National Highway Traffic Safety Administration's Restraint Use Strategy Workshop, Crystal City, VA, 2000 